\title{
Evaluasi Keunggulan Bersaing Bank XYZ Unit Bisnis Purna Bakti
}

\begin{tabular}{ccc} 
Nur Rahmawati & \\
\multicolumn{3}{c}{ IST AKPRIND Yogyakarta } \\
e-mail: rahma @akprind.ac.id & \\
\hline Diterima & Direvisi & Disetujui \\
$04-12-2020$ & $13-01-2021$ & $19-01-2021$ \\
\hline
\end{tabular}

\begin{abstract}
Abstrak - Bank XYZ dikenal sebagai bank yang memiliki peranan dalam melayani pembayaran manfaat pensiun maupun penyaluran kredit pensiun, khususnya pada unit bisnis Purna Bakti memiliki citra kuat sebagai bank mass market di Indonesia dengan pelayanan yang menggabungkan antara misi bisnis dan sosial. Munculnya beberapa Bank pesaing dalam melayani pembayaran manfaat pensiun maupun penyaluran kredit pensiun menjadikan permasalahan pada Bank XYZ untuk mempertahankan leading position dalam kredit pensiun. Penelitian ini bertujuan untuk mengidentifikasi faktor internal perusahaan dalam mencapai keunggulan bersaing dan melakukan evaluasi keunggulan bersaing pada Bank XYZ Purna Bakti. Peneliti menggunakan analisis internal perusahaan dari aspek sumber daya, kompetensi inti, kapabilitas, dan seluruh aktivitas rantai nilai perusahaan untuk melakukan evaluasi keunggulan bersaing. Hasil dari penelitian ini menunjukkan bahwa perusahaan memiliki sumber daya dengan reputasi tinggi, memiliki kompetensi inti dalam memberikan pelayanan sebagai misi bisnis dan sosial, memiliki kapabilitas tim manajemen yang handal, serta kesatuan seluruh aktivitas rantai nilai perusahaan yang saling mendukung. Perusahaan juga telah melakukan strategi diferensiasi dalam mencapai keunggulan bersaing dari segi pelayanan yang berbeda dibandingkan pesaingnya sehingga memberikan nilai tambah yang bersifat jangka panjang dan sulit untuk ditiru.
\end{abstract}

Kata Kunci: Keunggulan bersaing, Kompetensi inti, Sumber daya, Kapabilitas, Analisis rantai nilai, Diferensiasi

\begin{abstract}
XYZ Bank, is well known for it's first rate service to pension in both pension benefit payment and pension loan installment. Purna Bakti unit in particular is highly valued as a mass market bank segment in Indonesia which integrating business and social mission. The challenge going forward is to sustain the Bank's market leadership position, especially with increasing competition from other banks with same specialization. The research is purposed to analyze internal factor in a company to gain competitive advantage and evaluate this competitive advantage. The method of internal analysis will be used to identify company's strong point namely core competence, resources, capabilities, and whole value chain activities. The result shows that XYZ Bank has reputable resources, excellent core competence in their services, capable team management, and supportive value chain activities to command in a whole company. The Bank has been successfully implementing differentiation strategy to gain competitive advantage from different service perspective which giving it long-term strong point and making it distinct from another company.
\end{abstract}

Keywords: Competitive advantage, Core Competence, Resources, Capabilities, Value Chain, Differentiation

\section{PENDAHULUAN}

Bisnis pensiun adalah bidang usaha yang telah digeluti dan dan menjadi tulang punggung perkembangan Bank XYZ selama 50 tahun. Kekuatan bisnis model pensiun telah terbukti dapat melewati berbagai siklus ekonomi selama periode tersebut. Pondasi utama bisnis model pensiun adalah jasa pembayaran Tunjangan Hari Tua (THT) dan pembayaran pensiun bulanan melalui kerjasama dengan mitra utama strategis, utamanya adalah TASPEN, dan Dana Pensiunan antara lain Dana Pensiun Pertamina, Dana Pensiun Telkom, Dana Pensiun Perhutani, ASABRI, dan mitra pensiun lainnya.
Tren portofolio peningkatan kredit pensiun Bank XYZ pada unit bisnis Purna Bakti pada awalnya mengalami pertumbuhan yang pesat dan menjadi leading position dalam kredit pensiun. Tantangan ke depan adalah mempertahankan posisi kepemimpinan Bank di pasar, terutama dengan meningkatnya persaingan dari bank lain.

Munculnya beberapa bank pesaing yang menjalin kerjasama kemitraan dengan TASPEN dan organisasi pengelola pensiun lain baik pensiunan BUMN maupun pihak swasta dalam melayani pembayaran manfaat pensiun dan kredit pension menjadikan permasalahan pada Bank XYZ Purna Bakti untuk mempertahankan kepercayaan mitra 
dalam melayani pembayaran manfaat pensiun serta menjadi leading position dalam kredit pensiun.

Berdasarkan latar belakang permasalahan, maka pembahasan penelitian ini untuk menganalisis faktor internal yang ada dalam perusahaan untuk mencapai keunggulan bersaing dalam lingkungan eksternal yang dinamis. Analisis internal digunakan untuk mengidentifikasi kekuatan internal perusahaan yang berupa kompetensi inti, sumber daya, kapabilitas dan seluruh aktivitas rantai nilai perusahaan agar mampu menjawab tantangan dan peluang dari lingkungan eksternal serta melakukan evaluasi keunggulan bersaing pada Bank XYZ Purna Bakti.

Tujuan dilakukannya penelitian ini adalah sebagai berikut:

1. Mengidentifikasi faktor internal perusahaan dalam mencapai keunggulan bersaing Bank XYZ Purna Bakti.

2. Melakukan evaluasi keunggulan bersaing Bank XYZ Purna Bakti

\section{Keunggulan Bersaing (Competitive Advantage)}

Menurut (Porter, 1985) keunggulan bersaing adalah nilai yang mampu diciptakan oleh sebuah perusahaan untuk pembelinya yang melebihi biaya perusahaan dalam menciptakan suatu produk atau jasa. Nilai yang unggul berasal dari tawaran harga yang lebih rendah daripada pesaing untuk memberikan manfaat yang sama atau memberikan manfaat unik yang lebih dari sekedar mengimbangi harga yang lebih tinggi. Dasar suatu perusahaan untuk memperoleh kinerja jangka panjang dalam mempertahankan keunggulan bersaing di pasar adalah kepemimpinan biaya dan diferensiasi (Porter, 1985).

Kepemimpinan biaya adalah keunggulan bersaing yang menekankan pada biaya terendahnya di industri dalam menjadi penyedia barang atau jasa secara keseluruhan. Dengan biaya yang rendah maka akan meningkatkan keuntungkan perusahaan dari para pesaing. Strategi kepemimpinan biaya memberikan kemampuan daya saing perusahaan terhadap para pesaingnya. Posisi biaya rendah akan mampu bertahan dalam menghadapi pemasok yang kuat karena fleksibilitas dalam menanggulangi kenaikan biaya masuk. Selain itu, dengan biaya rendah akan dapat menjadi kendala bagi perusahaan baru untuk masuk dalam persaingan dan mampu memproteksi perusahaan dari lima kekuatan kompetitif (Porter, 1980).

Diferensiasi adalah keunggulan bersaing yang menekankan deferensiasi produk yang ditawarkan kepada pasar sehingga produk atau jasa yang ditawarkan tersebut berbeda dengan yang ditawarkan para pesaingnya. Dengan adanya diferensiasi yang luas maka penjualan produk akan mengalami peningkatan karena produk yang dijual menarik dan memiliki keunikan atau diferensiasi dari produk pesaing. Diferensiasi yang dilakukan tidak hanya pada penjualan dan periklanan akan tetapi peningkatan diferensiasi juga dilakukan pada produk, kinerja, customer service, aktivitas penelitian dan pengembangan, inovasi pengembangan teknologi, proses quality control, proses input produksi, manajemen sumber daya manusia dalam mengembangkan keterampilan dan pengetahuan pekerja (David, 2011)

Sumber yang paling menonjol dari keunggulan bersaing dapat ditemukan dalam struktur biaya bisnis dan kemampuannya untuk membedakan bisnis dari pesaing. Bisnis yang menciptakan keunggulan bersaing dari salah satu atau kedua sumber ini biasanya menghasilkan profitabilitas tinggi atau rata-rata dalam industri sedangkan bisnis yang tidak memiliki keunggulan biaya atau diferensiasi biasanya memiliki profitabilitas di bawah rata-rata (Pearce \& Robinson, 2009).

Suatu perusahaan memiliki keunggulan bersaing ketika perusahaan dapat menghasilkan nilai ekonomis yang lebih tinggi dibandingkan dengan pesaingnya, sedangkan perusahaan berada pada competitive parity ketika satu perusahaan menghasilkan nilai ekonomis yang sama dengan pesaingnya. Untuk mencapai keunggulan bersaing satu perusahaan harus menemukan sumber daya dan kapabilitas perusahaan yang unik serta bagaimana perusahaan mampu menggunakan keunikan tersebut dalam memilih dan mengimplementasikan strategi (Barney, 2002).

\section{Analisis Lingkungan Internal}

Perusahaan memanfaatkan kekuatan internal untuk mengeksploitasi kekuatan eksternal, mengurangi kelemahan internal, dan mengurangi ancaman dari eksternal. Perusahaan yang baik memiliki kemampuan untuk mengidentifikasi kekuatan internal yaitu kompetensi inti, sumber daya, kapabilitas dan seluruh aktivitas agar mampu menjawab tantangan dan peluang dari lingkungan eksternal. Kekuatan internal perusahaan juga harus mampu mengikuti perubahan eksternal perusahaan yang bergerak secara dinamis (Rothaermel, 2015).

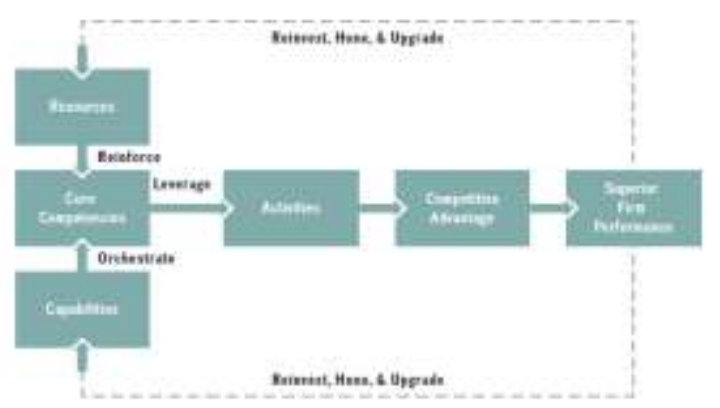

Sumber: Rothaermel, Frank T. Strategic Management, Third edition, Mc Graw Hill Education, New York, 2015

Gambar 1. Internal Analysis 
Kompetensi inti (core competence) terletak di dalam perusahaan yang tidak terlihat, akan tetapi dengan mengetahui produk dan jasa unggulan yang dimiliki oleh suatu perusahaan maka akan menjadi faktor penting untuk mencapai dan mempertahankan keunggulan bersaing. Perusahaan akan mengembangkan kompetensi inti melalui interaksi sumber daya dan kapabilitas. Sumber daya (resources) merupakan aset yang dimiliki oleh perusahaan seperti uang kas, bangunan, mesin, dan kekuatan intelektual perusahaan yang dapat digunakan pada saat penyusunan dan pelaksanaan strategi. Sumber daya dapat berupa sumber daya berwujud maupun tidak berwujud. Kapabilitas (capabilities) merupakan kemampuan organisasi dan manajerial yang berguna untuk mengintegrasikan sumber daya yang dimiliki untuk mencapai tujuan perusahaan. Aktivitas (activities) merupakan suatu kegiatan proses bisnis seperti pemesanan produk, pengiriman produk, pembuatan faktur kepada pelanggan (Rothaermel, 2015).

Kompetensi inti adalah hasil pembelajaran kolektif dalam suatu organisasi untuk mengkoordinasikan keterampilan produksi dan mengintegrasikan berbagai teknologi (Prahalad \& Hamel, 1990). Kompetensi inti adalah sesuatu yang dikerjakan oleh suatu perusahaan relatif lebih baik dari aktivitas-aktivitas internal yang lain, suatu kompetensi istimewa (a distinctive competence) adalah sesuatu yang dikerjakan oleh perusahaan relatif lebih baik dari pesaing-pesaingnya. Dengan kompetensi inti maka sumber keunggulan bersaing suatu perusahaan akan sulit untuk ditiru, memberikan nilai produk yang lebih baik kepada pelanggan, dan memudahkan perusahaan beradaptasi terhadap perubahan lingkungan karena akses potensial yang dimilikinya pada berbagai produk dan pasar (Thompson Jr., Arthur A., Strickland, 2014).

Sumber daya akan mampu menciptakan keunggulan bersaing melalui integrasi beberapa sumberdaya. Sumber daya memiliki nilai dalam suatu perusahaan jika sumber daya tersebut memiliki kontribusi untuk menunjang apa yang dibutuhkan oleh pelanggan, sumber daya tersebut langka atau memiliki keunikan sehingga tidak dapat digantikan dan tidak mudah ditiru oleh pesaing, serta dapat menciptakan nilai tambah bagi perusahaan.

Sumber daya perusahaan dinyatakan bernilai ketika sumber daya tersebut digunakan untuk implementasi strategi hingga dapat menghasilkan keefektifan dan efisiensi. Sumber daya dikatakan langka apabila sumber daya tersebut tidak dimiliki oleh perusahaan lain terutama perusahaan pesaingnya. Hal ini menunjukan bahwa sumber daya yang langka dan bernilai akan menjadi sumber keunggulan bersaing berkelanjutan bila perusahaan pesaing yang tidak memiliki sumber daya tersebut tidak mampu memperoleh sumber daya itu. Artinya, perusahaan pesaing tidak dapat meniru strategi yang dilakukan dan tidak dapat mengimitasi sumber daya yang dibutuhkan untuk pelaksanaan strategi tersebut (Purnomo, 2011).

Menurut (Thompson Jr., Arthur A., Strickland, 2014) kapabilitas merupakan kapasitas atau kemampuan perusahaan untuk mengintegrasikan sumber daya yang dimiliki untuk mencapai tujuan yang diinginkan. Kapabilitas akan menjadi kompetensi inti apabila memenuhi kriteria keunggulan bersaing yang berkelanjutan, yaitu sukar ditiru, memiliki nilai tambah, langka, dan tidak ada produk pengganti.

\section{Analisis Rantai Nilai (Value Chain)}

Analisis rantai nilai (value chain) merupakan alat analisis strategis yang digunakan untuk memahami secara lebih baik terhadap keunggulan kompetitif yang dilakukan untuk mengidentifikasi apakah value pelanggan dapat ditingkatkan atau penurunan biaya, dan untuk memahami secara lebih baik hubungan perusahaan pemasok/supplier, pelanggan, dan perusahaan lain dalam industri. Analisis rantai nilai mengidentifikasikan dan menghubungkan berbagai aktivitas strategis dalam perusahaan. Sifat rantai nilai tergantung pada sifat industri dan berbeda-beda untuk perusahaan manufaktur, perusahaan jasa dan organisasi yang tidak berorientasi pada laba (Porter, 1985).

\begin{tabular}{|c|c|c|c|c|c|}
\hline \multicolumn{5}{|c|}{ Firm Infrastructure } & \multirow{5}{*}{ Mar } \\
\hline & \multicolumn{3}{|c|}{ Humai Resource Margquement } & & \\
\hline & \multicolumn{3}{|c|}{ Techigologr Dereloprnent } & & \\
\hline & & Procurement & & & \\
\hline $\begin{array}{l}\text { Inbound } \\
\text { Logistics }\end{array}$ & Operations & $\begin{array}{l}\text { Outbound } \\
\text { Logistics }\end{array}$ & $\begin{array}{l}\text { Marketing } \\
\text { \& Sales }\end{array}$ & Service & \\
\hline
\end{tabular}

Sumber: Porter, Michael E. Competitive Advantage: Creating and Sustaining Superior Performance, The Free Prees, New York, NY, 1985

Gambar 2. Analisis Value Chain

Aktivitas-aktivitas perusahaan dapat dibagi menjadi sembilan kegiatan yang bernilai, yaitu lima aktivitas primer (primary activities) dan empat aktivitas pendukung (support activities). Aktivitas primer dalam sebuah perusahaan terdiri dari kegiatankegiatan yang berhubungan dengan input dan output barang dan jasa perusahaan yang terdiri dari lima kategori, yaitu inbound logistic, operation, outbound logistic, marketing/sales, dan services. Aktivitas pendukung di dalam suatu perusahaan merupakan kegiatan menfasilitasi proses produksi suatu produk yang terdiri dari empat kategori, yaitu procurement, technology development, human resources management, dan firm Infrastructure (Porter, 1985).

\section{METODE PENELITIAN}




\section{Desain Penelitian}

Penelitian ini termasuk penelitian diskriptif dengan pendekatan kualitatif. Penelitian kualitatif merupakan penelitian yang berisikan suatu rangkaian teknik penerjemahan yang berupaya menjelaskan, mentransformasikan, menerjemahkan, dan menjelaskan makna, bukan hanya sekedar frekuensi dari suatu kejadian sosial yang kurang lebihnya terjadi secara alami (Cooper \& Donald R Schindler, 2011).

Penelitian deskriptif digunakan untuk menggambarkan fenomena terkait dengan populasi subyek atau untuk memperkirakan proporsi dari populasi yang memiliki karakteristik tertentu. Tujuan utama riset deskriptif adalah untuk menggambarkan karakteristik sebuah populasi atau fenomena yang sedang terjadi. Penelitian ini dilakukan untuk menjawab pertanyaan tentang: siapa (who), apa (what), kapan (when), dimana (where), dan bagaimana (how) yang berkaitan dengan karakteristik populasi atau fenomena tersebut (Wibisono, 2008).

Penelitian kualitatif instrumennya adalah orang (human instrument), yaitu peneliti sendiri. Untuk dapat menjadi instrumen, maka peneliti harus memiliki bekal teori dan wawasan luas, sehingga mampu bertanya, menganalisis, memotret, dan mengkonstruksi situasi sosial yang diteliti menjadi lebih jelas dan bermakna. Metode kualitatif digunakan untuk mendapatkan data yang mendalam, suatu data yang mengandung makna. Penelitian kualitatif tidak menekankan pada generalisasi, tetapi lebih menekankan pada makna (Sugiyono, 2016).

\section{Metode Pengumpulan Data}

Data yang digunakan oleh peneliti dalam penelitian ini berupa data primer dan data sekunder. Data primer penelitian yang berasal dari sumber secara langsung, tanpa melalui media perantara (Cooper \& Donald R Schindler, 2011).

Data primer didapatkan dengan wawancara langsung dengan pejabat manajemen level puncak (Top-Level Management) Bank XYZ Purna Bakti yaitu Business Analytics, Sales, and Marketing Management Head of Pension Business dan Business Development Head of Pension Business. Peneliti juga melakukan observasi partisipatif dan membuat laporan penelitian secara detail.

Data sekunder diperoleh secara tidak langsung melalui media perantara atau data yang diperoleh dan dicatat oleh pihak lain yang telah disusun serta dipublikasikan (Cooper \& Donald R Schindler, 2011). Data sekunder dilakukan melalui kajian literatur dari berbagai sumber seperti buku, jurnal ilmiah, surat kabar, internet maupun sumber lainnya untuk mendapatkan informasi awal terkait penelitian yang dilakukan. Dalam penelitian ini, data sekunder digunakan dalam membantu menjelaskan landasan-landasan teori, penelitian terkait maupun sebagai data awal yang dapat menunjang penelitian.

\section{Metode Analisis Data}

Metode analisis data kulaitatif adalah proses proses mencari dan menyusun secara sistematis data yang diperoleh dari hasil wawancara, observasi, catatan lapangan, dan bahan-bahan lain sehingga mudah dipahami, dan dapat diinformasikan kepada orang lain (Sugiyono, 2016).

Analisis data dilakukan secara sistematis yang diperoleh dari hasil wawancara, observasi, catatan lapangan, dan bahan-bahan lain sehingga mudah dipahami, dan dapat diinformasikan kepada orang lain. Analisis data kualitatif dilakukan sejak sebelum memasuki lapangan, selama di lapangan, dan setelah selesai di lapangan. Dalam penelitian ini, peneliti menggunakan analitas internal perusahaan dari aspek sumber daya (resources), kompetensi inti (core competence), kapabilitas (capabilities), aktivitas (activity), dan analisis rantai nilai (value chain) untuk melakukan evaluasi keunggulan bersaing Bank XYZ Purna Bakti.

\section{HASIL DAN PEMBAHASAN}

\section{A. Analisis Lingkungan Internal}

Berdasarkan hasil penelitian, faktor internal Bank XYZ Purna Bakti dalam mencapai keunggulan bersaing yaitu sumber daya, kompetensi inti, kapabilitas dan seluruh aktivitas perusahaan. Hasil penelitian tersebut telah sejalan dengan teori (Rothaermel, 2015) bahwa perusahaan yang baik memiliki kemampuan untuk mengidentifikasi kekuatan internal yaitu kompetensi inti, sumber daya, kapabilitas, dan seluruh aktifitas agar mampu menjawab tantangan dan peluang dari lingkungan eksternal yang bergerak secara dinamis dalam mencapai keunggulan bersaing.

\section{Kompetensi Inti}

Kompetensi inti Bank Bank XYZ Purna Bakti dapat terlihat dari keunggulan bersaing yang dimiliki dibandingkan pesaingnya. Unique Value Proposition Bank XYZ terletak pada cara pelayanan yang menggabungkan antara misi bisnis dan sosial. Untuk mengubah dan meningkatkan kesejahteraan rakyat Indonesia, Bank XYZ Purna Bakti melaksanakan tanggung jawab sosialnya dengan memberikan pelayanan yang bagus dan solusi keuangan terhadap pensiunan sehingga Bank XYZ Purna Bakti selain memberikan pembayaran manfaat pensiun juga dapat menjadi sahabat pensiunan.

Bank XYZ memberikan akses ke pasar potensial dengan adanya program Daya tumbuh komunitas yang mendukug komunitas Purna Bakti untuk meningkatkan keterampilan dan keberhasilan usahanya. Bank XYZ tidak hanya sekedar memberikan pinjaman kepada para pensiun namun juga berfungsi sebagai solusi keuangan dengan melakukan pelatihan kewirausahaan, meningkatkan keterampilan pensiun, serta membantu memasarkan produk-produk dari nasabah Bank XYZ melalui bazar 
dan peluncuran e-commerce pasar daya untuk membantu nasabah meraih pasar yang lebih luas sebagai wujud kontribusi yang signifikan terhadap nasabah.

\section{Sumber Daya}

Bisnis pensiun (Bank XYZ Purna Bakti) mencatat total kredit sebesar Rp37,9 triliun, dan mempertahankan posisinya sebagai kontributor utama bagi total kredit Bank, dengan porsi $65 \%$ dari total kredit, tumbuh 9\% di 2015. Rasio kredit bermasalah (NPL) bruto terjaga pada $0,7 \%$, sama seperti tahun sebelumnya, sementara biaya kredit (Cost of Credit atau CoC) sedikit meningkat menjadi 1,4\%. Rasio NPL dan CoC Bank yang rendah dapat tercapai karena bisnis pensiunnya (Bank XYZ Purna Bakti) yang besar, dengan rasio NPL Bruto sebesar $0,1 \%$ sehingga kualitas aset Bank terjaga pada tingkat yang tinggi. Kredit pensiun pada Bank XYZ Purna Bakti didukung oleh pembayaran pensiun bulanan secara rutin oleh pemerintah. Selain itu, pinjaman ini dilindungi oleh polis asuransi jiwa yang berlaku bagi para debitur pensiun individu. Inilah sebabnya kredit pensiun memiliki kualitas tinggi, sebagaimana tercermin dari rasio kredit bermasalah (NPL) yang hanya mencapai 0,1\% (BTPN, 2016).

Manajemen memiliki pemahaman yang baik dalam mengelola permodalan Bank, dimana Direksi dan Dewan Komisaris memandang perencanaan permodalan sebagai elemen penting untuk mencapai tujuan strategis Bank dengan melakukan analisis atas kecukupan modal Bank saat ini dan masa mendatang dengan proses perencanaan strategis. Hal ini ditunjukkan dengan kinerja Bank yang terus dijaga, melalui pengawasan terhadap kualitas manajemen risiko secara berkesinambungan, Satuan Kerja Audit Internal (SKAI) melakukan pemeriksaan secara regular, kecukupan kebijakan mengenai pembagian dividen, serta komitmen manajemen terhadap strategi dan sasaran kerja Bank yang telah dituangkan ke dalam Rencana Bisnis Bank.

Dalam pelaksanaan prinsip Good Corporate Governance (GCG ) Bank XYZ memiliki tata kelola kecukupan struktur dan infrastruktur yang memadai yaitu pelaksanaan tugas, tanggung jawab dan independensi Dewan Komisaris, Direksi serta Komite, pengendalian internal dan penerapan manajemen risiko yang kuat, penerapan budaya kepatuhan dalam pengambilan keputusan dan dalam kegiatan operasional Bank serta pemenuhan aspek transparansi laporan keuangan dan non keuangan telah mendorong kinerja Bank yang cukup baik atas inisiatif strategis dan sasaran yang telah ditetapkan. Selain itu, pertumbuhan Bank telah memberikan manfaat ekonomis dan non ekonomis bagi stakeholders terutama pangsa pasar yang dilayani Bank yang didukung pula dengan layanan program Daya yang memberikan pelatihan dan layanan bernilai tambah lainnya.

\section{Kapabilitas}

Bank XYZ Purna Bakti memiliki tim manajemen yang handal untuk mengintegrasikan sumber daya yang dimiliki agar mencapai tujuan sesuai dengan visi dan misi perusahaan. Kapabilitas terus dikembangkan melalui pengembangan sumber daya manusia dan bekerjasama dengan pihak ketiga. Bank XYZ Purna Bakti melakukan behaviour market research yang bekerjasama dengan pihak ketiga karena unit bisnis Purna Bakti belum memiliki bagian khusus Research \& Development (R\&D). Research tersebut memberikan pengetahuan dan informasi kebutuhan nasabah terkait tujuan penggunaan manfaat pensiun serta tujuan pengambilan kredit.

\section{B. Evaluasi Keunggulan Bersaing Bank XYZ Purna Bakti}

Bank XYZ Purna Bakti melakukan diferensiasi untuk mencapai dan mempertahankan keunggulan bersaing. Diferensiasi dilakukan dari segi pelayanan untuk menawarkan sesuatu yang berbeda dibandingkan pesaingnya. Perusahaan telah memiliki nilai tambah yang bersifat jangka panjang, sulit untuk ditiru para pesaingnya dengan didukung oleh tim manajemen yang handal dan efektif sehingga dapat mengintegrasikan seluruh sumber daya, kapabilitas, kompetensi inti, dan seluruh aktivitas yang dimiliki oleh perusahaan.

Tabel 1. Hasil Evaluasi Keunggulan Bersaing Bank XYZ Purna Bakti

\begin{tabular}{|l|l|}
\hline \multicolumn{1}{|c|}{ Activities } & \multicolumn{1}{|c|}{ Evidence Competitive Advantage } \\
\hline Inbound & $\begin{array}{l}\text { "Bank XYZ Purna Bakti melakukan } \\
\text { inovasi menyiapkan supply dengan } \\
\text { cara memberikan fasilitas kredit bagi } \\
\text { pegawai aktif yang telah dilakukan } \\
\text { sejak 3 tahun yang lalu." (Yose } \\
\text { Parlinta, 2016) }\end{array}$ \\
\hline \multirow{5}{*}{ Operations } & $\begin{array}{l}\text { "Operation mendukung pembayaran } \\
\text { manfaat pensiun dengan datang lebih } \\
\text { awal dan memiliki tanggungjawab } \\
\text { atas ketersediaan dana, men-support } \\
\text { kebersihan serta menjaga keamanan } \\
\text { gedung untuk memberikan } \\
\text { kenyamanan bagi nasabah." (Esterina } \\
\text { Silitonga, 2016) }\end{array}$ \\
\hline Outbond & $\begin{array}{l}\text { "Hal yang menjadikan Bank menjadi } \\
\text { market leader adalah respon yang } \\
\text { cepat dari Bank XYZ untuk meng- } \\
\text { create suatu produk yang selaras } \\
\text { dengan perkembangan eksternal." } \\
\text { (Yose Parlinta, 2016) } \\
\text { "Dalam proses marketing, perusahaan } \\
\text { melihat behaviour dan needs nasabah } \\
\text { pensiunan sehingga Bank XYZ Purna } \\
\text { Bakti lebih banyak masuk ke } \\
\text { komunitas, paguyuban pensiunan, dan } \\
\text { word of mouth. (Enrico Novian, } \\
\text { 2016) }\end{array}$ \\
\hline Marketing \\
Sales
\end{tabular}




\begin{tabular}{|c|c|}
\hline Services & $\begin{array}{l}\text { "Seluruh karyawan Bank XYZ Purna } \\
\text { Bakti harus memberikan kenyamanan } \\
\text { bagi nasabah dengan motto "melayani } \\
\text { seperti orang tua sendiri". Bank XYZ } \\
\text { Purna Bakti membuat totally different } \\
\text { design khusus pensiunan sehingga } \\
\text { nasabah muat lebih banyak dan bisa } \\
\text { bersosialisasi. Bank XYZ Purna Bakti } \\
\text { memiliki produk yang simple, syarat } \\
\text { simple dan prosesnya cepat. Selain itu, } \\
\text { Bank XYZ memiliki program daya." } \\
\text { (Enrico Novian, 2016) }\end{array}$ \\
\hline $\begin{array}{l}\text { Firm } \\
\text { Infrastructure }\end{array}$ & $\begin{array}{l}\text { "Bank XYZ Purna Bakti } \\
\text { mengembangkan infrastrutur dari segi } \\
\text { kemudahan. Nasabah berhak untuk } \\
\text { memilih pembayaran manfaat pensiun } \\
\text { dengan beberapa pilihan yaitu nasabah } \\
\text { bisa melalui Cabang, ATM, Payment } \\
\text { Point ataupun kerjasama dengan agen } \\
\text { pihak ketiga." (Enrico Novian, 2016) }\end{array}$ \\
\hline $\begin{array}{l}\text { Human } \\
\text { Resources } \\
\text { Management }\end{array}$ & $\begin{array}{l}\text { "Untuk mengubah mindset karyawan } \\
\text { dengan perkembangan teknologi yang } \\
\text { semakin dinamis dilakukan dengan } \\
\text { cara sosialisasi, pemahaman terus } \\
\text { menerus, dan pemahaman yang } \\
\text { bermula dari atasan, jika atasan telah } \\
\text { memiliki mindset dan pemahaman } \\
\text { yang sama terkait inovasi untuk } \\
\text { mempertahankan keunggulan bersaing } \\
\text { maka akan memudahkan proses ke } \\
\text { bawahnya." (Enrico Novian, 2016) }\end{array}$ \\
\hline $\begin{array}{l}\text { Technology } \\
\text { Development }\end{array}$ & $\begin{array}{l}\text { "Kartu ATM dilengkapi dengan chip } \\
\text { sebagai kartu identitas nasabah, chip } \\
\text { tersebut merekam sidik jari nasabah } \\
\text { yang digunakan sebagai identitas } \\
\text { nasabah untuk melakukan otentifikasi } \\
\text { sekaligus pengambilan secara tunai." } \\
\text { (Yose Parlinta, 2016) }\end{array}$ \\
\hline Procurement & $\begin{array}{l}\text { "Pengadaan barang dilakukan melalui } \\
\text { vendor pihak ketiga agar memperoleh } \\
\text { barang atau jasa dengan biaya yang } \\
\text { terbaik dari segi kualitas dan } \\
\text { kuantitas." (Enrico Novian, 2016) }\end{array}$ \\
\hline
\end{tabular}

Sumber: Data Primer Diolah Penulis (2016)

Keunggulan bersaing Bank XYZ Purna Bakti paling utama terletak pada sisi pelayanannya yang memberikan nilai tambah bersifat jangka panjang, yaitu:

1. Kenyamanan pelayanan

Bank XYZ Purna Bakti memberikan pelayanan yang memberikan kenyamanan bagi nasabah dengan motto "melayani seperti orang tua sendiri".

2. Mempunyai desain pelayanan khusus untuk pensiunan

Bank XYZ Purna Bakti memiliki desain Cabang yang sangat berbeda dibandingkan Bank lain. Bank XYZ Purna Bakti memiliki desain khusus untuk pensiunan. Desain tersebut berbentuk seperti island karena pada dasarnya orang tua senang untuk berkumpul sehingga membutuhkan tempat yang luas untuk bisa berkumpul dan bersosialisasi.

3. Memiliki produk dan proses pelayanan cepat
Produk yang dimiliki Bank XYZ Purna Bakti memiliki persyaratan yang mudah, proses pelayanan cepat, suku bunga bersaing, serta fleksibilitas dalam menentukan nilai dan jangka waktu kredit untuk memenuhi berbagai kebutuhan. Untuk pencairan kredit pensiun bagi nasabah baru dapat diproses dalam jangka waktu satu hari atau maksimal dua hari kerja, sedangkan untuk renewal (top up) maka proses dilakukan satu jam.

4. Memiliki Program Daya

Program daya merupakan kegiatan Corporate Social Responsibility (CSR) Bank XYZ yang merupakan peluang sekaligus panggilan dalam mengintegrasikan misi sosial dan bisnis dalam produk dan layanan serta kegiatan bank. Daya terus menjadi platform Bank XYZ untuk menciptakan misinya "menciptakan kesempatan untuk tumbuh" dan visinya "mengubah berjuta hidup rakyat Indonesia". Tiga pilar utama daya terdiri dari program dan kegiatan yang berfokus pada daya sehat sejahtera (kesehatan), daya tumbuh usaha (pengembangan usaha), dan daya tumbuh komunitas.

\section{Analisis Rantai Nilai}

Analisis rantai nilai mengidentifikasikan dan menghubungkan berbagai aktivitas strategis dalam perusahaan. Analisis tersebut menunjukkan bahwa keunggulan bersaing Bank XYZ Purna Bakti merupakan suatu rangkaian kesatuan dari beberapa aktivitas maupun proses yang tidak dapat dipisahkan satu per satu.

Bank XYZ Purna Bakti merupakan salah satu unit bisnis yang fokus pada segmen pensiunan dan pra pensiunan. Bank XYZ Purna Bakti terus memperluas layanan keuangannya dengan menawarkan produk ke karyawan aktif dan pegawai negeri sipil selain segmen pensiunan pada umumnya, dan mereka yang tengah mempersiapkan diri untuk pensiun. Bank XYZ Purna Bakti mempertahankan kepemimpinan pasarnya dalam layanan keuangan bagi pensiunan melalui perluasan layanan untuk kaum prapensiunan dan memberikan kenyamanan ekstra melalui akses layanan perbankan digital dan jaringan cabang yang lebih luas. 


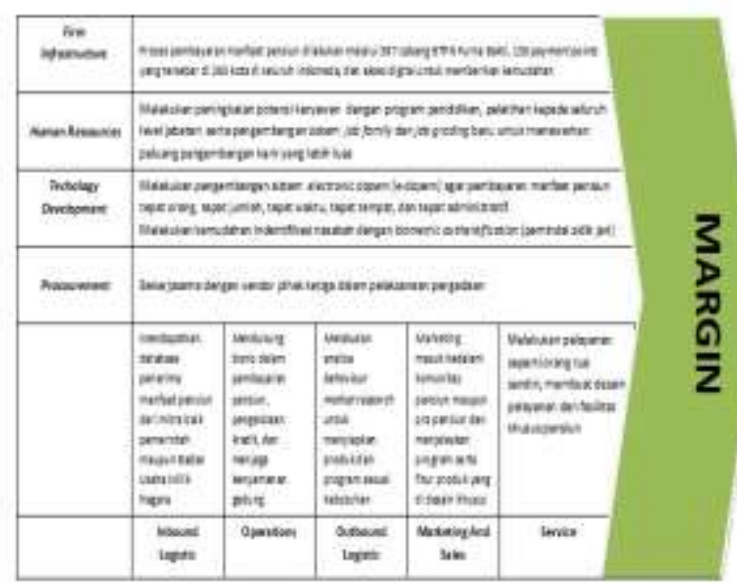

Sumber: Data Primer Diolah Penulis (2016)

\section{Gambar 3. Analisis Rantai Nilai Bank XYZ Purna Bakti}

\section{A. Aktifitas Primer}

\section{Inbound Logistic}

Bank XYZ Purna Bakti melakukan kerjasama dengan 34 mitra yang berasal dari instansi pemerintahan, Badan Usaha Milik Negara (BUMN), Badan Usaha Milik Daerah (BUMD), dan Dana Pensiun. Mitra akan memberikan list database penerima manfaat pensiun baru yang pembayaran manfaat pensiun dilakukan melalui Bank XYZ Purna Bakti.

\section{Operation}

Aktivitas yang dilakukan operation adalah mendukung bisnis dalam pembayaran manfaat pensiun maupun proses kredit pensiun, dan menjaga keamanan gedung. Operation memiliki Program Tangguh untuk melakukan efisiensi dari segala aspek dan Program Tulus sebagai program untuk meningkatkan sinergi antar Line of Business (LOB).

\section{Outbound Logistic}

Bank XYZ Purna Bakti melakukan kerjasama dengan pihak ketiga dalam market research behavior untuk mendapatkan informasi kebutuhan nasabah terkait tujuan penggunaan manfaat pensiun serta tujuan pengambilan kredit. Survey dilakukan untuk mengetahui apakah proses marketing dan pelayanan sudah sesuai dengan keinginan nasabah. Dari hasil survey tersebut maka manajemen akan melakukan proses review dan analisa biaya yang dikeluarkan dan keuntungan yang didapatkan dari program yang dijalankan, apabila program yang dijalankan dampaknya tidak efektif dalam pertumbuhan bisnis maka program tersebut akan dihentikan.

\section{Marketing/Sales}

Aktivitas pemasaran yang dilakukan Bank XYZ Purna Bakti adalah masuk kedalam komunitas dan paguyuban pensiunan. Tenaga pemasaran harus memiliki passion untuk menggali informasi nasabah terkait dengan kegiatan maupun komunitas yang dijalankan dan menjelaskan program yang dijalankan Bank XYZ Purna Bakti.

\section{Services}

Bank XYZ Purna Bakti sangat mengutamakan kemudahan dan kenyamanan dalam pelayanan kepada nasabah dengan motto "melayani seperti orang tua sendiri”. Bank XYZ Purna Bakti memiliki desain pelayanan khusus untuk nasabah pensiunan yang dilengkapi dengan fasilitas khusus orang tua dan sebagai sarana kegiatan komunitas, dan proses yang cepat dalam pemberian fasilitas kredit.

\section{B. Aktifitas Pendukung Firm Infrastructure}

Proses pembayaran manfaat pensiun dilakukan melalui 387 cabang, 130 payment points yang tersebar di 263 kota di seluruh Indonesia, dan pengembangan akses digital untuk memberikan kemudahan bagi nasabah. Dari segi efisiensi, perluasan jaringan pembayaran manfaat pensiun melalui Payment Point pada kantor pemerintahan misalnya kelurahan, kecamatan, maupun rumah nasabah yang hanya dilayani 5 (lima) hari pertama pada awal bulan lebih efisien daripada penambahan cabang baru karena biaya pembukaan cabang baru akan sangat besar.

\section{Human Resources}

Human Capital mengembangkan sistem job family dan job grading yang menawarkan peluang pengembangan karir yang lebih luas bagi karyawan. Untuk meningkatkan potensi karyawan dilakukan program pelatihan dan rotasi pekerjaan kepada seluruh karyawan untuk semua level jabatan. Dalam peningkatan kualitas sumber daya manusia Bank XYZ Purna Bakti melakukan standarisasi agar staf di Cabang memiliki pemahaman produk, prosedur maupun pelayanan yang standar dengan tes KYPP setiap 6 (enam) bulan sekali, pelatihan dan sertifikasi kredit pensiun (SKP), interview terhadap nasabah tentang feedback Cabang, adanya mistery shopper, dan Quality Service Asessment yang dilakukan oleh tim Quality Assurance.

\section{Technology Development}

Dari segi peningkatan kepercayaan mitra, Bank XYZ Purna Bakti saat ini melakukan perbaikan pelaporan kepada mitra guna memberikan laporan yang tepat orang, tepat jumlah, tepat waktu, tepat tempat, dan tepat administrasi. Bank XYZ Purna Bakti juga telah memiliki server elektronik Dapem ( $e$ dapem) yang terkoneksi secara online terhadap mitra TASPEN dan ASABRI. E-dapem adalah data elektronik yang berisi data dana pensiun (dapem) induk, dapem susulan, dan dapem khusus sebagai salah satu sarana pembayaran pensiun bulanan sehingga memudahkan mitra setiap saat dalam 
melihat Laporan Realisasi Pembayaran Pensiun (LRPP) dan Laporan Saldo Uang Pensiun (LSUP) terkait berapa nasabah yang sudah mengambil manfaat pensiunan maupun jumlah saldo yang tersisa pada rekening nasabah. Sistem tersebut juga dapat merekap jenis pengambilan nasabah baik pengambilan sediri atau pengambilan dengan surat kuasa.

\section{Procurement}

Pengadaan barang dilakukan melalui vendor pihak ketiga untuk mendapatkan barang, jasa atau pekerjaan dari sumber eksternal luar agar memperoleh barang, jasa atau pekerjaan yang tepat dan dibeli dengan biaya yang terbaik dari segi kualitas dan kuantitas, waktu, dan lokasi untuk memenuhi kebutuhan. Untuk melindungi risiko hukum, proses pengadaan harus memenuhi dokumen yang mengatur syarat dan ketentuan (perjanjian) yang menjadi dasar kerja sama antara Bank dengan vendor.

\section{KESIMPULAN}

Berdasarkan hasil analisis yang telah diuraikan pada bagian sebelumnya maka dapat diperoleh kesimpulan sebagai berikut:

1. Faktor internal perusahaan dalam mencapai keunggulan bersaing Bank XYZ Purna Bakti yaitu memiliki sumber daya dengan reputasi tinggi, memiliki kompetensi inti dalam memberikan diferensiasi pelayanan sebagai misi bisnis dan sosial, memiliki kapabilitas tim manajemen yang handal, serta memiliki kesatuan seluruh aktivitas rantai nilai perusahaan baik aktivitas primer maupun aktivitas pendukung yang saling mendukung untuk mengidentifikasi aktivitas potensial pada perusahaan.

2. Keunggulan bersaing Bank XYZ Purna Bakti sudah berjalan dengan baik yaitu dengan melakukan diferensiasi. Perusahaan telah memiliki nilai tambah yang bersifat jangka panjang, sulit untuk ditiru para pesaingnya dengan didukung oleh tim manajemen yang handal dan efektif sehingga dapat mengintegrasikan seluruh sumber daya, kapabilitas, dan kompetensi inti yang dimiliki oleh perusahaan. Keunggulan bersaing paling utama terdapat dari segi pelayanan yang berbeda dibandingkan kompetitor baik dilakukan kepada mitra maupun nasabah.

Hasil penelitian ini mendukung teori Porter (1985) bahwa dasar suatu perusahaan untuk memperoleh kinerja jangka panjang dalam mempertahankan keunggulan bersaing di pasar adalah kepemimpinan biaya dan diferensiasi. Perusahaan melakukan diferensiasi untuk mencapai dan mempertahankan keunggulan bersaing, selain itu perusahaan memiliki unique value proposition sebagai nilai yang unggul berasal dari tawaran harga yang lebih rendah daripada pesaing untuk memberikan manfaat yang sama atau memberikan manfaat unik yang lebih dari sekedar mengimbangi harga yang lebih tinggi.

\section{REFERENSI}

Barney, J. B. (2002). Gaining and sustaining competitive advantage. In Pearson Prentice Hall, New Jersey.

BTPN. (2016). Annual Report BTPN.

Cooper \& Donald R Schindler. (2011). Business Research Methods. In McGraw Hill, New York.

David, F. R. (2011). Strategic Management: Concepts and Cases (Thirteenth Edition). In Prentice Hall.

Pearce, J. A., \& Robinson, R. B. (2009). Manajemen Strategis: Formulasi, Implementasi, dan Pengendalian. In Jakarta: Salemba Empat.

Porter, M. E. (1985). Competitive Advantage. Creating and sustaining superior performance. In The Free Press, New York.

Prahalad, C. K., \& Hamel, G. (1990). The core competence and the corporation. Harvard Business Review.

Purnomo, R. (2011). Resource-Based View dan Keunggulan Bersaing Berkelanjutan: Sebuah Telaah Kritis Terhadap Pemikiran Jay Barney ( 1991 ). Proceeding Seminar Nasional \& Call For Papers (SCA-1).

Rothaermel, F. (2015). Strategict Managment, 3rd edition. In Mc Graw Hill Education, New York.

Sugiyono, P. D. (2016). Metode penelitian kuantitatif, kualitatif,dan R\&D. In Alfabeta, $C V$.

Thompson Jr., Arthur A., Strickland, A. J. (2014). Strategic Management-concept and cases. 19th edition. In McGraw-Hill, New York.

Wibisono. (2008). Riset Bisnis: Panduan Bagi Praktisi dan Akademisi. In Riset Bisnis: Panduan Bagi Praktisi dan Akademisi. 